\title{
FAKTOR-FAKTOR YANG BERHUBUNGAN DENGAN PENGGUNAAN ALAT PELINDUNGDIRI (APD) PADA PETUGAS PENYAPU JALAN DINAS LINGKUNGAN HIDUP KOTA JAMBI TAHUN 2020
}

\author{
Ulanda Nita Kurnia, Asparian, Lia Nurdini \\ Fakultas Kedokteran dan IImu Kesehatan Universitas Jambi \\ Corresponding author email: ulandakurnia@gmail.com
}

\begin{abstract}
Improving the health and safety of works is hazards control by using personal protective equipment (PPE) with thw work occupational standard health and safety program. There are several personal factors associated with workers using personal protective equipment (PPE) at work, including knowledge, attitudes, age, education level and years of service. The reseach objective was determinan serval factor reated to using personal protective equipment (PPE) of road sweepers in Jambi City. This type of research was a quantitative study by using a Cross Sectional approach. The results of this reseach a relations between most of responden have of female gender 92,0\%, with material status of a married worker $96,0 \%$ and the work area street sweeping officers in Telanai 26,7\%, work area in Kota Baru 17,3\% and Thehok 13,3\%. Fakctor related to of personal protective equipment (PPE) are knowledge (PR=1,600, 95\% $C l=1,223-2,093)$, attitude ( $P R=1,444,95 \% C l=1,172-1,781)$, years of service $(P R=1,07195 \% C l=0,758$ 1,513 ) Factors no related to use of personal protective equipment (PPE) age ( $P R=1,194, C l=0,740$ 1,927), education level ( $P R=1,219,95 \% \mathrm{Cl}$ 0,928-1,603). There were a relations between knowledge, attitude and years of service of personal protective equipment (PPE). There is no relationship between age and education level with the use personal protective equipment.
\end{abstract}

Keywords: Knowledge, Attitude, PPE, Officer Street Sweeper

\begin{abstract}
ABSTRAK
Salah satu upaya meningkatkan kesehatan dan keselamatan tenaga kerja yai-tu dengan pengendalian bahaya-bahaya yang mungkin terjadi saat berada di ling- kungan kerja dengan menggunakan alat pelindung diri sesuai dengan standar yang telah ditentukan dalam program keselamatan dan kesehatan kerja (K3). Banyak faktor yang mempengaruhi penggunaan alat pelindung diri (APD) meliputi pengetahuan, sikap, umur, tingkat pendidikan dan masa kerja. Tujuan penelitian ini ada- lah untuk mengetahui beberapa faktor yang berhubungan dengan penggunaan alat pelindung diri (APD) pada petugas penyapu jalan Dinas Lingkunga Hidup KotaJambi. Penelitian ini menggunakan desain case control. Populasi adalah seluruh petugas penyapu jalan Kota Jambi. Faktor yang berhubungan dengan penggunaan APD pada petugas peyapu jalan yaitu pengetahuan pengetahuan ( $P R=1,600,95 \% \mathrm{Cl}=1,223-2,093$ ), sikap (PR $=1,444,95 \% \mathrm{Cl}=1,172-1,781)$ dan masa kerja $(\mathrm{PR}=1,07195 \% \mathrm{Cl}=0,758-1,513)$ dan masa kerja $(\mathrm{PR}$ $=1,07195 \% \mathrm{Cl}=0,758-1,513)$ dan faktor yang tidak berhubungan yaitu umur $(\mathrm{PR}=1,194 \mathrm{Cl}=0,740-$
\end{abstract}


1,927), tingkat pendidikan ( $\mathrm{PR}=1,21995 \% \mathrm{Cl}$ 0,928-1,603). Maka dapat disimpulkan ada hubungan antara pengetahuan, sikap dan masa kerja terhadap penggunaan alat pelindung diri (APD).

Kata Kunci: Pengetahuan, sikap, APD, penyapu jalan

\section{PENDAHULUAN}

Keselamatan dan kesehatan kerja merupakan suatu sikap berfkir yang dapat menghasilkan tindakan, dimana akan berpengaruh terhadap lingkungan kerja dan menjadikan bagain penting pada setiap langkah yang di jalankan oleh suatu perusahaan ataupun instansi kerja. Program keselamatan dan kesehatan kerja bertujuan agar tercipta sebuah kondisi berupa keamanan dan kenyamanan bagi setiap pekerja sehingga dapat meningkatkan derajat kesehatan yang optimal dan menjadikan pekerja yang sehat bukan hanya terbebas dari penyakit, cacat dan kelelahan tetapi sehat secara mental dan sosial $^{(1)}$ Setiap tempat kerja memiliki berbagai potensi bahaya yang dapat membahayakan kesehatan pekerja dan dapat menimbulkan penyakit akibat kerja. Walaupun perusahaan atau organisasi kerja menyediakan dan menerapkan alat pelindung diri (APD) yang dibutuhkan oleh pekerja, ditemukan berbagai faktor yang masih menjadi penyebab ketidakpatuhan tenaga kerja. ${ }^{(1)}$

UU No. 1 tahun 1970 Pasal 13 menyatakan barang siapa akan memasuki tempat kerja, di- wajibkan menaati semua petunjuk keselamatan kerja dan memakai alat pelindung diri. Berkai- tan dengan upaya penerapan $\mathrm{K} 3$, pengunaan alat pelindung diri sebagai bagian dari pengendalian di tempat kerja merupakan syarat penting yang harus mendapat perhatian. ${ }^{(2)}$
Alat pelindung diri (APD) merupakan suatu perangkat yang digunakan tenaga kerja untuk melindungi dirinya dari potensi bahaya dan kecelakaan kerja yang mungkin dapat timbul ditempat kerja. Penggunaan alat pelindung diri saat melakukan pekerjaan merupakan suatu upaya pengendalian dari terpaparnya resiko bahaya ditempat kerja.Namun pada kenyataannya masih banyak ditemukan pekerja yang tidak menggunakan alat pelindung diri. ${ }^{(3)}$

Pekerja yang perlu mendapatkan perhatian dan apresiasi tinggi yang mendapatkan suatu penghargaan mengenai kebersihan Kota dan sekitarnya adalah pekerja penyapu jalan. Petugas penyapu jalan sangat berperan dalam terciptanya kebersihan jalan kota dengan adanya perkembangan pembangunan yang pesat, arus mobilitas penduduk yang tinggi sehingga banyakpembangunan jalan raya ${ }^{(1)}$ Peraturan Daerah Kota Jambi No. 8 Tahun 2013 dalam pasal 10 tentang pengolahan sampah, dimana petugas penyapu jalan yang berjumlah 329 orang menjadi salah satu personil petugas kebersihan yang bertugas menyapu sampah dan mengumpulkan sampah di sepanjang jalan - jalan protokol, jalan utama, dan tempat - tempat umum di Kota Jambi.

Dengan waktu kerja dan lingkungan kerja yang memiliki risiko terpapar debu dan emisi kendaraan, maka kondisi tersebut dapat menimbulkan dampak kesehatan 
pada pekerja serta gangguan pada ekosistem maupun iklim.Umumnya gangguan kesehatan yang diakibatkan oleh pencemaran udara yang dapat menimbulkan penyakit akibat kerja pada saluran pernapasan dan gangguan pengelihatan (Triwibowo, 2013). Infeksi saluran pernapasan atas (ISPA) yang terjadi melalui udara, disebabkan oleh virus dan bakteri yang ada pada lingkungan kerja yang diawali dengan panas disertai salah satu atau lebih, gejala tenggorokan sakit atau rasa nyeri saat menelan, pilek, batuk kering atau berdahak (Muttaqin, 2008). Dari risiko yang dapat terjadi pada pekerja, petugas penyapu jalan sangat di anjurkan untuk menggunakan alat pelindung diri.(5)

Alat pelindung diri tetap penyapu jalan meliputi penutup kepala yang berfungsi melindungi kepala dari paparan sinar matahari, kacamata melindungi mata dari debu dan polusi yang dapatmasuk ke dalam mata, masker untuk mengurangi bau tak sedap dan mencegah debu masuk ke saluran pernafasan, baju dan celana panjang melindungi kulit dari paparan langsung sinar ma- tahari, sarung tangan digunakan untuk melindungi tangan dari bakteri atau zat yang berbahaya dari sampah, dan sepatu untuk melindungi kaki dari benda tajam dan jamur. Fakta ini terjadi pada penyapu jalan yang memiliki risiko kerja yang dapat terjadi kapan saja dengan waktu yang tidak ditentukan. (6)

Dengan risiko gangguan kesehatan dan keselamatan sebagai petugas penyapu jalan tergolong tinggi, karena banyak ditemukan hazard yang tinggi pada sampah yang berpotensi menimbulkan penyakit akibat kerja. Hasil temuan dalam penelitian Iqlima, pada petugas penyapu jalan masih banyak ditemukan pekerja yang tidak menggunakan alat pelindung diri berupa sarung tangan, masker dan sepatu bout dengan beralasan jika menggunakan sarung tangan saat bekerja dapat merepotkan proses saat bekerja, tidak menggunakan masker untuk menutup hidung melainkan hanya di pasang pada leher serta tidak menggunakan sepatu saat bekerja dikarenakan sepatu mengalami kerusakan sehingga hanya menggunakan sandal jepit saat bekerja. Dimana, penelitian ini sendiri dilakukan menggunakan beberapa variabel yakni penge- tahuan, sikap, dan pendidikan memiliki hubungan dengan kedisiplinan terhadap penggunaan APD karena nilai analisis chisquare menunjukkan angka yang cukup besar yaitu 34.250 pada variabel pengetahuan.(6)

Berdasarkan uraian diatas maka peniliti tertarik untuk melakukan penelitian tentang "Faktor-Faktor yang Berhubungan dengan Penggunaan Alat Pelindung Diri pada Pekerja Penya- pu Jalan di Dinas Lingkungan Hidup Kota Jambi Tahun 2020".

\section{METODE PENELITIAN}

Penelitian ini merupakan penelitian kuantitatif dengan desain studi case kontrol atau kasus kontrol. Desain studi case control digunakan pada penelitian ini dengan nilai distribusi normal pada tingkat kemaknaan 0,05\%. Penelitian ini dilakukan di Kota Jambi periode No- vember - Desember 2020. Populasi penelitian adalah seluruh petugas penyapu jalan di Kota Jambi dengan sampel penelitian berjumlah 75 
responden yang diambil menggunakan metode sampling accidenta. Data yang digunakan dalam penelitian ini adalah data primer yang di- peroleh menggunakan instrument penelitian berupa kuesioner dan lembar observasi yang te- lah lulus uji validitas dan reliabilitasnnya sebelumnya serta menggunakan lembar informed concent sebagai lembar persetujuan penelitian antara peneliti dengan responden. Data yang diperoleh diolah menggunakan secara univariat dan bivariat.

\section{HASIL DAN PEMBAHASAN}

\section{ANALISIS UNIVARIAT}

Berdasarkan Tabel.1, diketahui bahwa kategori jenis kelamin responden, sebagian besarberjenis kelamin perempuan yakni sebanyak 68 orang $(90,7 \%)$, status pernikahan reponden, sebagian besar sudah menikah yakni sebanyak 72 orang (96\%) dan wilayah kerja responden sebagian besar berada di Kecamatan Telanai sebanyak 20 orang(26,7\%).

Tabel 1. Distribusi Responden Berdasarkan Krakteristik Tahun 2020

\begin{tabular}{lcc}
\hline Karakteristik & $\begin{array}{c}\text { Jumlah } \\
(\mathbf{n}=\mathbf{7 5})\end{array}$ & $\begin{array}{c}\text { Persentase } \\
(\%)\end{array}$ \\
\hline Wilayah Kerja & & \\
\hline Alambarajo & 6 & $\mathbf{8}$ \\
Beringin & 5 & $\mathbf{6 , 7}$ \\
Danau Sipin & 3 & $\mathbf{4}$ \\
Jelutung & 6 & $\mathbf{8}$ \\
Kota Baru & 13 & $\mathbf{1 7 , 3}$ \\
Pal Merah & 7 & $\mathbf{9 , 3}$ \\
Pasar Jambi & 5 & $\mathbf{6 , 7}$ \\
Telanai & 20 & $\mathbf{2 6 , 7}$ \\
Thehok & 10 & $\mathbf{1 3 , 3}$ \\
& & \\
\hline
\end{tabular}

\begin{tabular}{lcr}
\hline Jenis Kelamin & & \\
\hline Laki-laki & 6 & $\mathbf{8}$ \\
Perempuan & 59 & $\mathbf{9 2}$ \\
\hline Status Pernikahan & & \\
\hline Menikah & 72 & $\mathbf{9 6}$ \\
Belum & $\mathbf{3}$ & $\mathbf{4}$ \\
Menikah & & \\
\hline
\end{tabular}

Berdasarkan Tabel.2 variabel pengetahuan responden, diketahui bahwa responden dengan pengetahuan buruk berjumlah 43 orang (57.3\%) sedangkan responden dengan penge- tahuan baik berjumlah 32 orang (42,7\%).Berdasarkan variabel sikap responden, diketahui bahwa responden dengan sikap positif berjumlah 36 orang $(48,0 \%)$ sedangkan responden dengan sikap negatif berjumlah 39 orang $(52,0 \%)$. Berdasarkan variabel usia responden, diketahui bahwa responden dengan kategori usia tua berjumlah 68 orang (90.7\%) sedangkan responden dengan kategori usia muda berjumlah 7 orang $(9,3 \%)$. Berdasarkan variabel tingkat pendidikan responden, diketahui bahwa responden dengan tingkat pendidikan rendah ber- jumlah 53 orang (70,2\%) sedangkan responden dengan tingkat pendidikan tinggi sebanyak 22 orang $(29,3 \%)$. Berdasarkan variabel masa kerja responden, diketahui bahwa responden dengan masa kerja baru berjumlah 47 orang $(62.7 \%)$ sedangkan dengan masa kerja kategori lama berjumlah 28 orang $(37,7 \%)$. Berdasarkan variabel alat pelindung diri responden, diketahui bahwa responden dengan penggunaan APD tidak lengkap berjumlah 63 orang (84.0\%) sedangkan responden dengan APD lengkap berjumlah 
12 orang $(81,7 \%)$.

Tabel 2. Distribusi Frekuensi Berdasarkan Variabel Independen Pada Petugas Penyapu Jalan Dinas Lingkungan Hidup Kota Jambi Tahun 2020

\begin{tabular}{lcc}
\hline Karakteristik & $\begin{array}{c}\text { Jumlah } \\
\text { (n=75) }\end{array}$ & $\begin{array}{c}\text { Persentas } \\
\text { e (\%) }\end{array}$ \\
\hline Pengetahuan & 53 & 70,7 \\
Buruk & 22 & 29,3 \\
Baik & & \\
\hline Sikap & 39 & 52,0 \\
Negatif & 36 & 48,0 \\
Positif & & \\
\hline Usia & 68 & 90,0 \\
Tua & 7 & 9,3 \\
Muda & & \\
\hline Tingkat Pendidikan & & 70,7 \\
Rendah & 53 & 9,3 \\
Tinggi & 22 & \\
\hline Masa Kerja & & 62,7 \\
Baru & 47 & 37,7 \\
Lama & 28 & 84,0 \\
\hline Penggunaan APD & & 16,0 \\
Tidak Lengkap & 63 & \\
Lengkap & 12 & \\
\hline
\end{tabular}

Berdasarkan Tabel.3 hasil

penelitian, didapaati bahwa penggunaan APD petugas penya- pu jalan menggunakan APD kriteria topi yang aman (82,7\%) sedangkan yang tidak aman (17,3\%), diikuti pakaian panjang $(92 \%)$, celana panjang $(93,3 \%)$, tidak menggunkan sarung tangan $(65,3 \%)$, menggunakan masker $(53,3 \%)$, tidak menggunakan sepatu booth $(80,0 \%)$.
Tabel 3. Ketersediaan APD Pengendara Ojek

Online di Kota Jambi Tahun 2020

\begin{tabular}{lcc}
\hline Ketersediaan APD & $\begin{array}{c}\text { Jumlah } \\
(\mathbf{n}=\mathbf{7 5})\end{array}$ & $\begin{array}{c}\text { Total } \\
(\%)\end{array}$ \\
\hline Menggunakan APD Sesuai & & \\
Prosedur & & \\
Tidak & 63 & 84,0 \\
Ya & 12 & 16,0 \\
\hline Menggunakan Topi & & \\
Tidak & 63 & 84,0 \\
Ya & 12 & 16,0 \\
\hline Menggunakan Topi yang Aman & & \\
Tidak & 62 & 82,7 \\
Ya & 13 & 17,3 \\
\hline Menggunakan Pakaian Panjang & & \\
Tidak & 6 & 8,0 \\
Ya & 69 & 92,0 \\
\hline Menggunakan Celana Panjang & & \\
Tidak & 5 & 6,7 \\
Ya & 70 & 93,3 \\
\hline Menggunakan Sarung Tangan & & \\
Tidak & 49 & 6,7 \\
Ya & 26 & 93,3 \\
\hline Menggunakan Masker & 35 & 46,7 \\
Tidak & 60 & 53,3 \\
\hline Ya & 15 & 20,0 \\
\hline Menggunakan Sepatu Booth & & \\
Tidak & & \\
Ya & & \\
\hline Menggunakan Sepatu Booth & 18,7 \\
dengan Kondisi Baik & & \\
Tidak & & \\
Ya & & \\
\hline & & \\
\hline
\end{tabular}




\section{ANALISIS BIVARIAT}

Berdasarkan Tabel 4. hasil analisis bivariat dengan uji statistik Chi-square. Dapat diketahui bahwa ada hubungan antara pengetahuan dengan penggunaan APD pada petu- gas penyapu jalan dengan hasil nilai $\alpha=0,000$ ( $p$-value $<0,05)$. Hasil analisis juga menjuk- kan nilai $P R=1,600$ (95\% Cl: 1,223-2093), yang berarti petugas penyapu jalan dengan pengetahuan burukmemiliki risiko tidak menggunakan APD saat bekerja 1,600 kali lebih besar dibandingkan petugas penyapu jalan yang memiliki pengetahuan baik. Didapatkan nilai tingkat kepercayaan 95\% (Cl 95\%) berada pada rentang batas bawah 1,223 dan batas atas 2,093 yang mana secara statistic terdapat hubungan yang bermakna.

Tabel 4. Hasil Analisis Bivariat Variabel yang Berhubungan dengan Penggunaan Alat Pelindung Diri (APD) Pada Petugas Penyapu Jalan Dinas Lingkungan Hidup Kota Jambi 2020

\begin{tabular}{|c|c|c|c|c|c|c|c|c|}
\hline \multirow{3}{*}{ Variabel } & \multicolumn{4}{|c|}{ Penggunaan APD } & & & \multirow{3}{*}{$\begin{array}{l}P \text { - } \\
\text { value }\end{array}$} & \multirow{3}{*}{$\begin{array}{c}\text { PR } \\
(95 \% \mathrm{Cl})\end{array}$} \\
\hline & \multicolumn{2}{|c|}{ Lengkap } & \multicolumn{2}{|c|}{ Tidak Lengkap } & \multicolumn{2}{|c|}{ Total } & & \\
\hline & (n) & $(\%)$ & (n) & (\%) & $(n=75)$ & $(\%)$ & & \\
\hline \multicolumn{9}{|l|}{ Pengetahuan } \\
\hline Baik & 43 & 63,3 & 0 & 00,0 & 43 & 57,3 & 0,000 & 1,600 \\
\hline Buruk & 20 & 31,7 & 12 & 100,0 & 32 & 42,7 & & $(1,233-2,093)$ \\
\hline \multicolumn{9}{|l|}{ Sikap } \\
\hline Positif & 27 & 42,9 & 12 & 100,0 & 36 & 52,0 & 0,001 & 1,444 \\
\hline Negatif & 36 & 57,1 & 0 & 00,0 & 36 & 48,0 & & $(1,172-1,781)$ \\
\hline \multicolumn{9}{|l|}{ Usia } \\
\hline$>35$ tahun & 58 & 92,1 & 10 & 83,3 & 68 & 90,7 & 0,169 & 1,194 \\
\hline$\leq 35$ tahun & 5 & 7,6 & 2 & 16,7 & 7 & 9,3 & & $(0,509-1,094)$ \\
\hline \multicolumn{9}{|c|}{ Tingkat Pen-didikan } \\
\hline Rendah & 47 & 74,6 & 6 & 50,0 & 53 & 70,0 & 0,171 & 1,219 \\
\hline Tinggi & 1 & 25,4 & 6 & 50,0 & 22 & 29,3 & & $(0,928-1,630)$ \\
\hline \multicolumn{9}{|l|}{ Masa Kerja } \\
\hline Baru $<6$ tahun & 44 & 97,8 & 1 & 2,2 & 45 & 100,0 & 0,000 & 2,444 \\
\hline Lama $\geq 6$ tahun & 12 & 40,0 & 18 & 60,0 & 30 & 100,0 & & $(1,574-3,797)$ \\
\hline
\end{tabular}

Berdasarkan hasil analisis bivariat dengan uji statistik Chi-square. Dapat diketahui bahwa ada hubungan antara pengetahuan dengan penggunaan APD pada petugas penyapu jalan dengan hasil nilai $\alpha=0,001$ ( $p$-value $<0,05)$. Hasil analisis juga menjukkan nilai $\mathrm{PR}=1,444$ (95\% Cl: 1,172-1,781), yang berarti petugas penyapu jalan dengan sikap negatif memiliki risiko tidak menggunakan APD saat bekerja 1,444 kali lebih besar dibandingkan petugas penyapu jalan yang memiliki sikap positif. Didapatkan nilai tingkat kepercayaan 95\% (CI 95\%) berada pada rentang batas bawah 1,178 dan batas atas 1,172 yang mana secara statistic terdapat hubungan yang 
bermakna.

Berdasarkan hasil analisis bivariat dengan uji statistik Chi-square. Dapat diketahui bahwa tidak ada hubungan antara usia dengan penggunaan APD pada petugas penyapu jalan dengan hasil nilai $\alpha=0,169$ ( $p$-value $>0,05)$. Hasil analisis juga menjukkan nilai $\mathrm{PR}=1,194$ (95\% Cl: 0,740-1,927), yang berarti petugas penyapu jalan dengan usia $>35$ ta- hun memiliki risiko tidak menggunakan APD saat bekerja 1,195 kali lebih besar dibandingkan petugas penyapu jalan dengan usia $\leq 35$ tahun. Didapatkan nilai tingkat kepercayaan 95\% (Cl 95\%) berada pada rentang batas bawah 1,927 dan batas atas 0,74 yang mana secara statistic tidak terdapat hubungan yang bermakna.

Berdasarkan hasil analisis bivariat dengan uji statistik Chi-square. Dapat diketahui bahwa tidak ada hubungan antara usia dengan penggunaan APD pada petugas penyapu jalan dengan hasil nilai $\alpha=0,171$ ( $p$-value $>0,05)$. Hasil analisis juga menjukkan nilai $P R=1,219$ (95\% Cl: 0,928-1,603), yang berarti petugas penyapu jalan dengan tingkat pen- didikan rendah memiliki risiko tidak menggunakan APD saat bekerja 1,219 kali lebih be- sar dibandingkan petugas penyapu jalan dengan tingkat pendidikan tinggi. Didapatkan nilai tingkat kepercayaan 95\% (Cl 95\%) berada pada rentang batas bawah 1,603 dan b a-tas atas 0,928 yang mana secara statistik tidak terdapat hubungan yang bermakna.

Berdasarkan hasil analisis bivariat dengan uji statistik Chi-square. Dapat diketahui bahwa ada hubungan antara pengetahuan dengan penggunaan APD pada petugas penyapu jalan dengan hasil nilai $\alpha=0,000$ ( $p$-value $<0,05$ ). Hasil analisis juga menjukkan nilai $P R=2,444$ (95\% Cl: 1,574-3,797), yang berarti petugas penyapu jalan dengan masa kerja $\leq 6$ tahun memiliki risiko tidak menggunakan APD saat bekerja 2,444 kali lebih besar dibandingkan petugas penyapu jalan yang dengan masa kerja $>6$ tahun. Didapatkan nilai tingkat kepercayaan 95\% (Cl 95\%) berada pada rentang batas bawah 3,797 dan batas atas 1,574 yang mana secara statistik terdapat hubungan yang bermakna.

Hasil analisis bivariat pada penelitian ini menunjukkan bahwa terdapat hubungan bermakna antara pengetahuan dengan penggunaan alat pelindung diri (APD). Hal ini dapat terjadi karena pada kelompok petugas penyapu jalan dengan pengetahuan buruk sebagian besar tidak menggunakan alat pelindung diri saat bekerja $(68,3 \%)$ sedangkan pada petugas dengan pengetahuan baik sebanyak $(31,7 \%)$. Pada penelitian ini juga dapat kita lihat petugas penyapu jalan dengan pengetahuan buruk memiliki risiko 1,600 kali tidak menggunakan alat pelindung diri dibandingkan dengan petugas pen- yapu jalan dengan pengetahuan baik, sehingga variabel pengetahuan merupakan variabel yang memiliki hubungan yang bermakna dan merupakan faktor yang mempengaruhi penggunaan alat pelindung diri (APD). Hasil penelitian ini mendukung teori Lawreen Green (1980) yang menyatakan bahwa pengetahuan merupakan salah satu faktor yang 
mempermudah perilaku seseorang yang disebut faktor predisposisi yang merupakan satu diantara 3 faktor penentu perilaku. Penelitian yang dilakukan oleh Sahriani.R pada petugas penyapu jalan dengan penggunaan APD di Gunungtua Kabupaten Padang Lawas Utara yang menyatakan bahwa terdapat hubungan antara pengetahuan dengan penggunaan alat pelindug diri (APD) dengan analisi uji Chi- square didapatkan hasil nilai $p$ value $=0,000$ dengan responden perpengatahuan baik yang tidak menggunakan APD (26,0\%) sedangkan responden dengan pengetahuan ku- rang $(52 \%)$ hal ini terjadi karena kurangnya pengetahuan seseorang tentang bahaya tidak menggunakan alat pelindung diri (APD) akan menimbulkan kecelakaan kerja atau penyakit akibat kerja. ${ }^{(1)}$ Hasil penelitian ini menunjukkan sebagian petugas pen- yapu jalan memiliki pengetahuan yang buruk terhadap penggunaan APD (68,3\%). Ber- dasarkan hasil wawancara dilapangan, petugas penyapu jalan Dinas Lingkungan Hidup Kota Jambi hanya menerina pelatihan penggunaan APD pada awal bekerja dan tidak dilakukan pelatihan lagi setelahnya. Peneliti berasumsi banyaknya petugas penyapu jalan yang memiliki pengetahuan buruk karena kurangnya peran dari pihak DinasLingkungan Hidup dalam mendukung program keselamatan dan kesehatan kerja ter- masuk didalamnya penggunaan APD saat bekerja. Pekerja yang tidak terlatih lebih cenderung tidak menggunakan APD yang merupakan salah satu penyebab penyakit akibat kerja. Memberikan pelatihan merupakan kunci utama untuk mengatur, men- gendalikan dan merubah perilaku manusia.

Dalam penelitian ini sikap responden Dari keseluruhan jawaban pada petugas pen- yapu jalan di Kota Jambi diperoleh sebesar 52,0\% responden yang memiliki sikap negatif terhadap penggunaan alat pelindung diri (APD) dan $48,0 \%$ memiliki sikap posi- tif. Responden dengan perilaku petugas penyapu jalan lebih banyak yang memiliki sikap negatif terhadap penggunaan APD sebesar 57,1\% dibandingkan dengan responden yang memiliki sifat positif terhadap penggunaan APD sebesar 42,9\%. Hal tersebut didukung dengan hasil uji Chi-square pada sikap dan perilaku penggunaan APD, diketahui bahwa terdapat hubungan antara sikap dengan penggunaan alat pelindung diri (APD). Sejalan dengan hasli penelitian sebelumnya yang dilakukan oleh Noviandhita.H (2014) pada petugas penyapu jalan di Kota Sintang, yang menyatakan bahwa terdapat hubungan antara sikap dengan penggunaan alat pelindung diri (APD) dengan analisis Chisquare di- peroleh nilai $\mathrm{P}=0,002$ dengan responden yang memiliki sikap postif dan tidak menggunakan APD saat bekerja sebanyak $25,0 \%$ serta responden yang memilki sikap negatif namun tidak menggunakan APD saat bekerja 78,9\%. Hasil penelitian ini juga menunjukkan bahwa petugas penyapu jalan yang memiliki sikap negative memiliki risi- ko 11,250 kali tidak menggunakan APD saat bekerja dibandingkan dengan petugas penyapu jalan yang memiliki sikap positif.(8) 
Dalam Lawrence Green (1980), dijelaskan bahwa sikap merupakan salah satu faktor yang mempengaruhi perilaku antara penge- tahuan dan faktor lainnya. Sikap dapat mengukur perilaku dan perubahan Perilaku mencakup tiga bidang yaitu pengetahuan, sikap dan perilaku.

Umur responden merupakan sebuah tanda lamanya waktu hidup pekerja sejak dilahirkan, terhitung dari tanggal lahir sampai pada waktu penelitian. Umur juga dapat diartikan sebagai salah satu faktor yang dapat mempengaruhi aktivitas seseorang da- lam kesehariannya, termasuk didalamnya aktivas bekerja. Dalam penelitain ini umur responden yang dikelompokkan menjadi dua yakni tua $>35$ tahuan dan muda $\leq 35$ ta- hun. Hasil penelitian ini dapat diketahui petugas penyapu jalan yang berusia $>35$ ta- hun tidak mengunakan alat pelindung diri saat bekerja sebanyak $83,3 \%$ dan usia $\leq 35$ tahun yang tidak menggunakan alat pelindung diri sebanyak $16,7 \%$. Dari hasil analisis menggunakan uji Chi-square didapatkan hasil nilai $p=0,161>0,05$ yang berati tidak terdapat hubungan yang bermakna antara umur pekerja dengan penggunaan alat pelindung diri. Hal ini sejalan dengan penelitian yang telah dilakukan oleh Ardhian- to.MR (2017) di wilayah kerja Kabupaten Gersik, didapatkan hasil analisis Chi-square nilai $\mathrm{p}=0,132>0,05$ yang artinya tidak terdapat hubungan yang bermakna antara umur pekerja dengan penggunaan alat pelindung diri (APD). Dimana responden dengan umur $\leq 36$ tahun yang menggunakan alat pelindung diri sebanyak $97 \%$ dan umur >
36 tahun yang menggunakan alat pelindung diri sebanyak $89 \%$. Hal tersebut terjadi karena perusahaan mempunyai komitmen yang tinggi dalam menegakkan kedi- siplinan dalam penggunaan APD. Berbagai usaha sudah dilaksanakan, seperti: penga- daan APD yang cukup baik, memberikan pengawasan secara ketat terhadap penggunaan APD dengan dilakukannya patroli rutin di area pabrik, pembentukan safe- ty representative di tiap bagian dan pemberian sanksi apabila melanggar aturan terkaitpenggunaan APD di tempat kerja, serta memberikan edukasi berupa pelatihan untuk para pekerja.(3) Berdasrkan penelitian dilapangan, diketahui bahwa persentase petugas penyapu jalan dengan kategori umur $>35$ tahun dan < 35 tahun yang tidak menggunakan alat pelindung diri (APD) saat bekerja memiliki jumlah yang sama ban- yaknya, hal ini terjadi karena petugas penyapu jalan yang menerima alat pelindung diri (APD) saat berkerja tidak dibedakan mealaui umur, dimana semua pekerja menerima alat peindung diri saat bekerja dan tindakan memberikan pelatian atau penyuluhan pada pekerja saat pertama kali masuk diberikan pada seluruh pekerja. Serta pengawasan yang diterima semua pekerja dilakukan secara merata dan tidak dibedakan berdasrkan umur pekerja tersebut.

Pendidikan secara umum ialah untuk memperluas pengetahuan, pengalaman serta pengertian seseorang, dengan harapan semakin tinggi pendidikan seorang pekerja maka semakin luas penetahuan seseorang dan akan lebih 
mudah dalam mendapatkan solusi alternative guna menyelesaikan pekerjaannya serta semakin tinggi daya inisiatifnya. Berdasarkan hasil dari penelitian yang telah dilakukan diketahui bahwa tingkat responden yang telah dikategorikan menjadi dua yakni rendah dan tinggi. Dimana responden dengan tingkat pendidikan rendah dalam penggunaan alat pelindung diri (APD) yang tidak lengkap yakni sebanyak $74,6 \%$ sedangkan tingkat pendidikan rendah sebanyak $25,4 \%$ dan hasil analisis yang diperoleh menggunakan uji Chi-square nilai $\mathrm{p}=1,171>0,05$ yang berarti tidak adanya hubungan yang bermakna antara tingkat pen- didikan dengan penggunan alat pelindung diri (APD). Hal ini sejalan dengan penelitian yang dilakukan oleh Seviana.R, dkk (2016) pada pekerja di wilayah $\mathrm{X}$, menyatakan bah- wa tidak adanya hubungan antara tingkat pendidikan pekerja dengan penggunaan alat pelindung diri (APD). Dengan hasil penelitian pekerja dengan tingkat pendidikan SMP yang tidak menggunakan alat pelindung diri sebanyak $38,2 \%$ sedangkan pekerja dengan pendidikan SMA yang tidak menggunakan alat pelindung diri yakni sebanyak $61,8 \%$, hal ini dikarenakan tingkat pendidikan tidak mempuyai pengaruh terhadap terbentuknya sikap seseorang. (33) Dari hasil penelitian dapat dilihat bahwa yang tidak menggunakan alat pelindung diri (APD) saat bekerja sebagian besar pada responden dengan tingkat pendidikan rendah dan sebagian kecil pendidikan tinggi, hal ini terjadi karena perusahaan memberikan pelatian mengenai APD tidak membedakan dari ting- kat pendidikan dan diberikan secara menyeluruh baik pekerja dengan tingkat pendidi- kan rendah maupun, sebab pekerja dengan tingkat pendidikan tinggi tidak menjamin seseorang akan patuh menggunakan alat pelindung diri saat bekerja bergitupun sebaliknya.

Dalam penelitian ini masa kerja merupakan salah satu faktor yang berhubungan dengan penggunaan alat pelindung diri (APD) pada petugas penyapu jalan, dimana masa kerja pada penelitian ini dibagi menjadi dua kategori yakni $<6$ tahun yang dikatakan masa kerja baru dan $\geq 6$ tahun masa kerja lama. Dari hasil penelitian dikethui bahwa hasil analisis menggunakan uji Chi-square denbgan nilai $\mathrm{p}=0,001<0,05$ dengan persentase pekerja baru yang tidak menggunkan APD saat bekerja adalah $97,8 \%$ dan pekerja lama yang tidak menggunakan APD 40,0\% serta pekerja yang menggunakan APD saat bekerja sebanyak 60,0\%. Hasil penelitian ini membuktikan te- ori yang dikemukakan oleh Lawrence Green (1998) dalam faktor predisposising bah- wa masa kerja mempengaruhi perilaku seseorang. Mendukung hasil penelitian ini, penelitian yang dilakukan oleh Khairuddin.D (2016) pada petugas penyapu jalan di wilayah kerja PT.MIFA Aceh Barat, menyatakan adanya hubungan masa kerja dengan penggunaan alat pelindung diri (APD) saat bekerja, dengan hasil penelitian menggunakan uji Chi-square dengan nilai $\mathrm{p}=0,030<0,05$ dan persentase pekerja yang tidak menggunakan APD saat bekerja 
dengan masa kerja baru $<1$ tahun yakni $73,7 \%$ sedangkan pekerja dengan masa kerja lama $\geq 1$ tahun yakni $31,2 \%$. Hal ini dikarenakanpengalaman kerja yang telah dilalui seseorang dalam jangka waktu yang lama me- nyebabkan seseorang dapat mengerti tentang dampak positif dan negatif dapat ditim- bulkan dari pekerjaan yang ditekuninya. Untuk mengurangi dampak negatif dari pekerjaannya sesuai dengan pengalamannya akan mengantisipasi dirinya dengan alat pelindung diri pada saat bekerja, yang mana bila alat tersebut tidak disediakan atau kesediaan bahannya sangat terbatas bisa saja seseorang memodifikasi beberapa bahan atau barang yang dapat digunakan untuk dijadikan alat pelindung diri, walaupun mungkin barang yang dimodifikasi tersebut tidak sepenuhnya memenuhi standar dari alat pelindung diri.(25) Fakta yang ditemukan dilapangan, berdasarkan hasil wawancara yang dilakukan dengan responden saat pengisian kuesioner bahwa pekerja dengan masa kerja lama $>6$ tahun memiliki pengetahuan yang baik terhadap risiko atau pen- yakit yang mungkin dapat mereka dapatkan saat bekerja sedangkan dengan pekerja dengan masa kerja baru < 6 tahun. Dimana pekerja dengan masa kerja yang lama juga terdapat beberapa yang pernah mengalami kecelakaan kerja seperti tertabrak oleh kendaraan, tersandung oleh sepatu booth yang digunakan saat bekerja maupun terlempar batu oleh orang yang ada dipinggir jalan (dalam kondisi tidak sehat mental), dari beberapa pengalaman yang sudah diterima oleh petugas penyapu jalan maka dari itu mereka lebih sadar atau lebih memperhatikan kemungkinankemungkinan buruk yang akan mereka terima saat bekerja.

\section{KESIMPULAN}

Ada hubungan antara pengetahuan dengan penggunaan alat pelindung diri (APD) dengan nilai hasil ( $P R=1,600,95 \%$ $\mathrm{Cl}=1,223-2,093)$. Ada hubungan antara sikap dengan penggunaan alat pelindung diri $(A P D)$ dengan $(P R=1,444,95 \% \mathrm{Cl}=$ 1,172-1,781). Tidak ada hubungan antara usia dengan penggunaan alat pelindung diri (APD) demham nilai $(P R=1,194 \mathrm{Cl}=$ 0,740 - 1,927). Tidak ada hubungan antara tingkat pen- didikan dengan penggunaan alat pelindung diri (APD) dengan nilai $(P R=1,21995 \% \mathrm{Cl}$ 0,9281,603). Ada hubungan antara masa kerja dengan penggunaan alat pelindung diri (APD) dengan nilai $(\mathrm{PR}=1,07195 \% \mathrm{Cl}=$ 0,758-1,513).

Diharapkan pihak Dinas Lingkungan Hidup dapat menyelaraskan tujuan dibentuknya petugas kebersihan (penyapu jalan) tidak hanya menggutamakan visi dan misi, juga dapat mendukung program keselamatan dan kesehatan kerja dengan meng- gaungkan secara inovatif dalam penyuluhan ataupun pelatian tentang pentingnya penggunaan APD saat bekerja. Diharapkan pihak Dinas Lingkungan Hidup meningkat- kan penyediaan APD serta memberikan alat pelindung diri (APD) sesuai dengan ukuran pekerja, khususnya APD sepatu booth.

Diharapkan petugas penyapu jalan 
dapat mengaplikasikan pengetahuan tentang pentingnya penggunaan alat pelindung diri (APD) saat bekerja dan lebih meningkatkan pengetahuan tentang penyakit akibat kerja. Diharapkan petugas penyapu jalan dapat membentuk dan menjadikan sebuah komunitas sebgai tempat pembelajaran dalam ber- tukar pengalaman saat bekerja.

Diharapkan peneliti lain melakukan penelitian lebuh lanjut dengan bahasan yang sama dengan mencari variabelvariabel dari penelitian ini agar dapat dibandingkan, dengan tujuan agar memperoleh pemahaman yang lebuh dalam mengenai perilaku penggunaan alat pelindung diri (APD) pada petugas penyapu jalan. Diharapkan peneliti lain melakukan penelitian dengan metode kualitatif agar mendapatkan hasil yang lebih dalam dan tidak sepihak.

\section{DAFTAR PUSTAKA}

1. Sahriani R. Faktor-Faktor Yang Berhubungan Dengan Penggunaan Alat Pelindung Diri Pada Penyapu Jalan Di Gunung Tua Kabupaten Padang Lawas Utara Tahun 2019. Kedua. Institut Kesehatan Helvita Medan; 2019.

2. Rahmawati R, Pratama A. Hubungan Pengetahuan, Pendidikan, dan Pelatihan dengan Tingkat Kepatuhan Penggunaan Alat Pelindung Diri (APD) Pada Petugas Penyapu Jalan di Kecamatan Bangkinang Kota Tahun 2018. 2018;3.

3. Andriyanto MR. Hubungan Predisposing Factor Dengan Perilaku Penggunaan Apd Pada Pekerja Unit Produksi PT Petrokimia Gersik. Indones J Occup Saf Heal. 2017;6(1):37.

4. Yeni DM. Peran Wanita Muslimah dalam Menunjang Perekonomian Keluarga di Kecamatan Telanaipura Kota Jambi (Study Kasus Pada Petugas Dinas Kebersihan Kota Jambi) [Internet]. Vol. 10, Gastrointestinal Endoscopy. Universitas Islam Negri Sulthan Thaha Saifuddin Jambi; 2018.

5. Sulasmi, Ibrahim. Faktor - Faktor yang Mempengaruhi Penggunaan Alat Pelindung Diri (APD) pada Penyapu Jalan di Sepanjang Jalan Veteran Kota Makassar. 2018;18:59-65.

6. Yulita II, Widjasena B, Jayanti S. Faktor yang Berhubungan dengan Disiplin Penggunaan Alat Pelindung Diri pada Penyapu Jalan di Kota Semarang. 2019;7:330-6.

7. Solekhah SA. FAKTOR PERILAKU KEPATUHAN PENGGUNAAN APD PADA PEKERJA PT $X$ COMPLIANCE BEHAVIOR OF PERSONAL PROTECTIVE EQUIPMENT USE. 2018;6(1):1-11.

8. Noviandita H. Faktor - faktor yang Berhubungan dengan Perilaku Kepatuhan Penggunaan Alat Pelindung Diri (APD) pada Petugas Penyapu Jalan di Kota Sintang 2014. Wawasan Kesehat. 2014;1:42-9.

9. Sertiya Putri KD. Analisis Faktor Yang Berhubungan Dengan Kepatuhan Menggunakan Alat Pelindung Diri. Indones J Occup Saf Heal. 2014;1:24-36.

10. Rofiq MA, Siregar SD, Wau H. Hubungan Penggunaan Alat Pelindung Diri (APD) dan Perilaku Kerja dengan Keselamatan Kerja pada Petugas Kebersihan di Kelurahan Petisah Tengah Tahun 2019. J Chem Inf Model. 2019;4:1-8.

11. Kurusi, Fazni D., Akili, Rahayu H., Punuh MI. Hubungan Antara Pengetahuan dan Sikap dengan Kepatuhan Penggunaan Alat Pelindung Diri (APD) pada Petugas Penyapu Jalan di Kecamatan Singkil dan Tuminting. J KESMAS, Vol 9, No 1, Januari 2020. 2020;9(1):45-51.

12. Katman. Menerapkan Prosedur keselamatan, Kesehatan Kerja. In Erlangga : Jakarta; 2008.

13. Peraturan Wali Kota. Tentang Fungsi Dinas, Sekretariat, Bidang Dan Rincian Tugas Sub Bagian, Seksi Serta Tata Kerja Pada Dinas Pasar. Jambi; 2013

14. Undang - Undang Keselamatan Kerja;1970.

15. Suma'mur. Keselamatan Kerja dan Pencegahan Kecelakaan. CV Haji Masagung : Jakarta;2009.

16. Harrianto R. Buku Ajar Kesehatan Kerja. EGC : Jakarta; 2009.

17. Buddiono A. S. Hiperkes dan Keselamtan Kerja. CV Haji Masagung : Jakarta; 1992.

18. Drs, Buntaro MP. Panduan Praktis Keselamatan Dan Kesehatan Kerja Untuk Industri. I. Yogyakarta: PUSTAKABARUPRESS; 2015.

19. Kuswana WS. Ergonomi dan K3 Keselamtan dan kesehatan kerja. Bandung: PT Remaja Rosdakkarya; 2014.

20. Djatmiko RD. Keselamatan dan Kesehatan Kerja. I. Yogyakarta: CV Budi Utama; 2016.

21. Palar H. Pencemaran dan Tosikologi Logam Berat. I. Jakarta: Rineka Cipta; 1994.

22. Fardiaz S. Polusi Air dan Udara. I. Jakarta: Karisius; 2002.

23. Sudarmaji. Toksikologi Logam Berat Berat B3 dan Dampak Terhadap Kesehatan. FakKesehat Masy 


\section{Erlangga. 2006;}

24. Notoatmodjo S. Promosi Kesehatan dan IImu Perilaku. Jakarta: Rineka Cipta; 2007.

25. Khairuddin D. Faktor - Faktor Yang Berhubungan Dengan Penggunaan Alat Pelindung Diri (Masker) Pada Petugas Penyapu Jalan PT.MIFA Aceh Barat Tahun 2016. Teuku Umar;2016.

26. Notoatmodjo S. Pendidikan dan Perilaku Kesehatan. Cipta R, editor. Jakarta; 2003.

27. Notoatmodjo S. Metodologi Penelitian Kesehatan. I. Jakarta: Rineka Cipta; 2005.

28. DR S. Manajemen Tenaga Kerja Indonesia. Jakarta: PT. Bumi Aksara Indonesia; 2003.

29. Muhib A. Pengantar Ilmu Pendidikan. Semarang: PT Unnespress; 2004.

30. Tulus MA. Manajemen Sumber Daya Manusia. Jakarta: Gramedia Pustaka; 2002.

31. Kurniawidjaja M. Teori dan Aplikasi Kesehatan Kerja. Jakarta: PT. Asdi Mhasatya; 2002.

32. Sedarmayanti. Sumber Daya Manusia dan Produktivitas Kerja. Bandung: Mandar Maju; 2001.

33. Rianwati S, Widowati NN, Rosanti E. Pengaruh Tingkat Pengetahuan Pelaksanaan Pemakaian Alat Pelindung DirinSebagai Upaya Pencapaian Zero Acident Di PT.X. J Ind Hyg Occup Heal. 2016;1(1):53-67.

34. Sugiyono. Memahami Penelitian Kualitatif. Bandung: CV. Alfabeta; 2005.

35. Rachman LA, Yulianto FA, Djojosugito MA, Andarini MY, Djajakusumah TS. Hubungan Pengetahuan dan Sikap terhadap Perilaku Penggunaan Alat Pelindung Diri di PT Sarandi Karya Nugraha Sukabumi. J Integr Kesehat Sains. 2020;2(2):154-9. 